\title{
DESAFIO DA FACETA CERÂMICA UNITÁRIA
}

Luciane Grochocki RESENDE, Joao Luiz Pereira NEVES, Danilo CALDAS, Rui MAZUR, Rodrigo Nunes RACHED

As cerâmicas são o material de eleição para as facetas, pois apresentam propriedades que permitem uma estética similar ao do esmalte dental. Na confecção da faceta cerâmica unitária existe o desafio de restabelecer a estética, forma, textura e cor similar aos dentes adjacentes. O objetivo desse trabalho é apresentar um caso clínico e seus procedimentos para confeccionar uma faceta em incisivo lateral devolvendo a estética satisfatoriamente. $\mathrm{O}$ resultado mostrou que apesar da dificuldade técnica em se conseguir a mimetização do dente homólogo, pela confecção da faceta cerâmica unitária, é possível se obter um resultado estético satisfatório. 